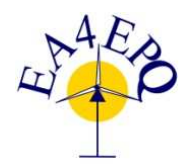

International Conference on Renewable Energies and Power Quality (ICREPQ'16) Madrid (Spain), $4^{\text {th }}$ to $6^{\text {th }}$ May, 2016

Reneuble Energy and Power Qualily. Fournal (RE\&PQJ)

ISSN 2172-038 X, No.14 May 2016

\title{
Solar energy: a source for water disinfection in Colombia
}

Carmen Leonor Barajas Forero

Department of Hydraulic, Fluids and Thermal Sciences

Francisco de Paula Santander University

Avenida Gran Colombia No.12E-96 Cucuta (Colombia)

e-mail: carmenleonorbf@ufps.edu.co

\begin{abstract}
Colombia, due to its geographical position, receives a high solar radiation throughout the year. This implies that the country has great potential for solar energy production, but can also use this resource to enhance the living conditions of its inhabitants by using solar radiation to improve the quality of drinking water.
\end{abstract}

Mainly in rural areas, the country has serious problems with drinking water for its inhabitants. This generates high morbidity and mortality, especially in children under five.

The main purpose of this preliminary work was to investigate if weather conditions in northeastern Colombia permit to use the sun's energy to disinfect water from water sources which are normally heavily contaminated. The results are encouraging and may lead to establish programs for appropriate use of this technology in areas where the construction of treatment plants very difficult.

Key words: Colombia, water disinfection, solar energy

\section{Introduction}

Due to its geographical position Colombia has a great availability of solar energy throughout the year. Overall, the country has a good sun energy potential throughout the territory, with a daily average multi-year close to $4.5 \mathrm{kWh} / \mathrm{m} 2$. The region with the highest solar radiation in the country is the peninsula of La Guajira and maximum values are presented in the month of July, with averages higher than $7.6 \mathrm{kWh} / \mathrm{m}^{2}$. This value gradually decreases until December, when the minimum value of $6.2 \mathrm{kWh} / \mathrm{m}^{2}$ is obtained. With the same behavior during the year, followed by the middle of the geographic valley of Cauca river, the Magdalena River valley to the Atlantic coast and the area of Cucuta. The extreme values occur in July and December values of 7.6 and 5.2 $\mathrm{kWh} / \mathrm{m}^{2}$, respectively.

In the Amazon, however, the maximum value occurs in October with $3.8 \mathrm{kWh} / \mathrm{m}^{2}$. In the Andean region excels Cundiboyacense, with peaks in February at levels of $5.6 \mathrm{kWh} / \mathrm{m}^{2}$, then gradually descend until June, minimum 4.8 $\mathrm{kWh} / \mathrm{m}^{2}$; again gradually increase until September, to descend until November. The rest of the Andean region has the same behavior during the year with lower values, with extremes of 4.6 and $3.7 \mathrm{kWh} / \mathrm{m}^{2}$ of February and June.

Areas with lower levels of radiation are the pacific coast and the foothills ranger in the surrounding area of Villavicencio, averaging less than $300 \mathrm{kWh} / \mathrm{m}^{2}$; during the year they have little variability, with the months of March and April the most radiation, while November and December 
are characterized by lower radiation months, with extreme values of 3.7 and $3.2 \mathrm{kWh} / \mathrm{m}^{2}(1)$. Specific information on solar radiation in different regions of Colombia can be seen in Figure 1.

\section{Drinking water in Colombia}

The environmental factors that contribute to premature deaths in Colombia are air pollution and indoor and outdoor water conditions, sanitation and hygiene (2). A study of the social and economic costs of environmental degradation in Colombia shows that "the adverse health effects related to environmental degradation are higher than in other countries with similar income levels, reaching a mortality and morbidity cost $2.8 \%$ of GDP" (3), which corresponds to approximately 5.2 billion pesos a year. The annual cost attributable to weather conditions, sanitation and hygiene in Colombia represent_about $1.1 \%$ of GDP (2).

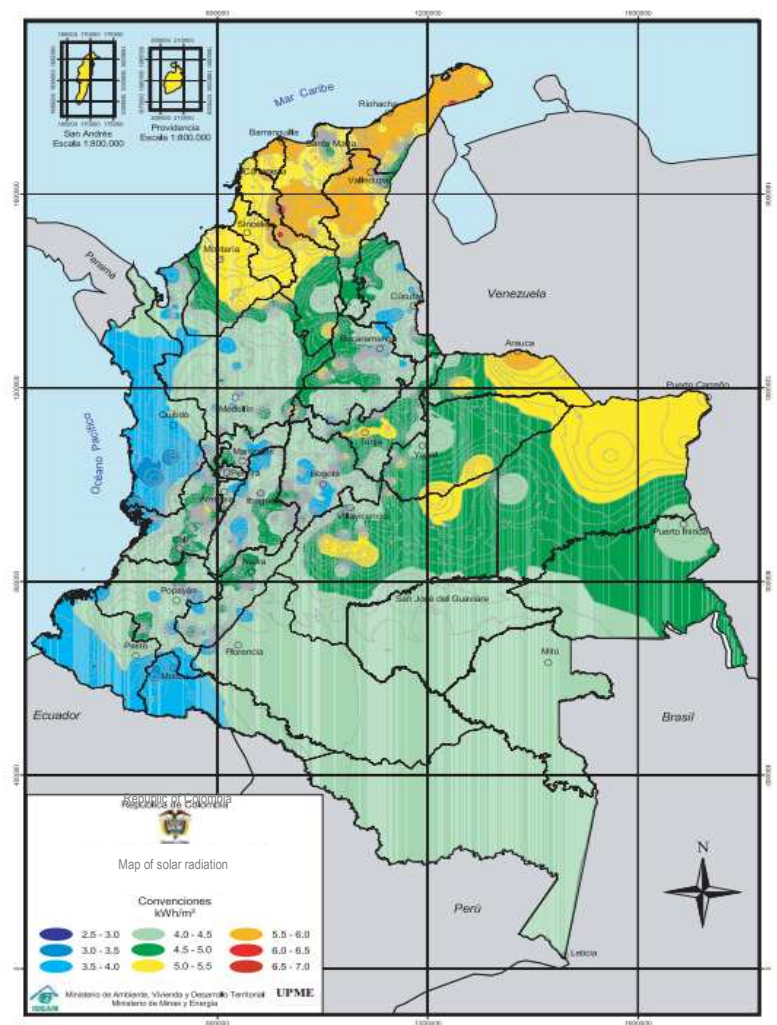

Figure 1. Colombia map of solar radiation. UPME, I. (1).

According to report by the Ministry of Health and Social Protection (4), in 2013, large urban centers, departmental capitals and the majority of intermediate cities were supplied with good quality water, while conditions of water supply in smaller municipalities and rural areas of the country presented a high health risk. This condition affects $30 \%$ of the population.
In rural areas of the country, especially in the North Santander department, the socioeconomic conditions limit and restrict the use of a proper process of water treatment and disinfection of the same, which causes health problems in communities. This fact allows us to conclude the urgent need to propose easy solutions and immediacy that allow resolve this situation. 
Currently, the most commonly used disinfectant is chlorine. This method of disinfection required technical personnel and appropriate equipment to control the dosage, which increases costs in the water treatment process.

Among the different existing alternative technologies for water disinfection, disinfection by solar energy, could be a good choice for the people of the Colombian countryside. This technology based on a cheap and renewable resource has shown to have the potential to achieve safe drinking water with minimal investment cost, when compared to traditional methods used in the country.

\section{Solar disinfection}

Solar disinfection (SODIS) of water in plastic bottles, is a well-known water treatment method utilized in communities lacking water treatment infrastructure. Water disinfection using solar energy has gained importance from research conducted by Acra and colleagues at the American University of Beirut (Lebanon) who found that the flow of ultraviolet radiation necessary to obtain inactivation levels of the order of $90-99.9 \%$ of Streptococcus faecalis, Escherichia coli and coliform was in the range of 6.36$26.72 \mathrm{Wh} / \mathrm{m}^{2}(5,6)$.

Solar disinfection has been investigated by EAWAG / SANDEC Swiss institute who have proposed this process for treating small amounts of water. This technology has also been studied by different researchers under a variety of weather conditions $(7,8,9,10$, Dessie, A.et $a l$, 2014). Different results have been obtained but they show a good possibility for using the method for treating water under good radiation conditions.

\section{Methods}

The main purpose of this preliminary work was to test the efficiency of the solar disinfection method under the climatological conditions of the northeast zone of Norte de Santander, in Colombia. The first step included analysis of the behavior of different material related to transmission of ultraviolet radiation. Samples of common materials used for packaging or bottling such as glass, polyethylene tereftatato (PET), polypropylene (PP), low density polyethylene (LDPE), were analized for UV transmission. A radiometer (MGUVB-101) calibrated by the Institute of Hydrology, Meteorology and Environmental Studies of Colombia,(IDEAM) was used in the experiments.

The proper amount of time needed to provide adequate disinfection and the effect of the plastic covering were both determined from solar exposure experiments. Sample water, simulating a possible unfit drinking water source was collected from a local river with heavy microbiological contamination.

The quality of water was quantitatively assessed through the enumeration of colony-forming units (CFUs) of total Coliforms and Escherichia coli, which was used as an indicator organism for fecal contamination. Analysis were performed following the Colombian technical standards, NTC ISO 5667-3, NTC 3645, NTC 3651, NTC 4707 and NTC 4772.

The water was then exposed to sunlight for one, three, five and eight hours. Air and water temperatures were recorded at each sampling.

Two liters PET containers, two liters glass and polypropylene bottles and two liter bags of low density polyethylene were used as reactor vessels. In order to evaluate the impact of physical interventions on the efficiency of microbial inactivation, the back of the half of the reactors was painted black. 


\section{Results}

The laboratory analyses were performed at around five turbidity levels to observe five data sets on different days. All the samples were analyzed for turbidity ${ }_{2}$ bottle temperature, atmospheric temperature, and $\mathrm{pH}$. The $\mathrm{pH}$ value of all the samples ranged between 6.5 and 7.5 during the entire experiment cycle.

For PET, at one hour the inactivation was 10,7\% for Coliforms and $23 \%$ for E. Coli. For five and eight hours the results were similar: $99,9 \%$ for inactivation of Coliforms and E. Coli. Inactivation decreased with turbidity, but still at 120 NTU a $95.2 \%$ of inactivation of Coliforms and $97 \%$ of E. Coli was reached. In some samples, after five hours of exposure microbial regrowth was found.

\section{Conclusions}

The inactivation of pathogens in contaminated natural water was investigated. Three different transmisor materials were analized. The best material for solar disinfection appeared to be polyethylene terephthalate, PET. The results of solar disinfection experiments conducted under local conditions are very encouraging. An average of $99,9 \%$ of microorganism inactivation was reached in 5 and 8 hours of exposure. More research should be done in order to find a process for treating larger amount of water.

\section{Acknowledgments}

This research was supported for the Research Fund of the Francisco de Paula Santander University.

\section{References}

1. UPME, I. (2005). Atlas de Radiación solar de Colombia. Santafé de Bogotá DC: Unidad de Planeación Minero Energética, Ministerio de Minas y Energía.

2. CONPES. Consejo Nacional de Política Económica y Social. 2008. Documento 3550.

Lineamientos para la formulación de la política integral de salud ambiental con énfasis en los componentes de calidad de aire, calidad de agua y seguridad química. Departamento Nacional de Planeación. Bogotá.

3. Larsen, B. (2004). Cost of environmental damage: A socioeconomic and environmental health risk assessment. Bogotá: Ministerio de Ambiente, Vivienda y Desarrollo Territoral.

4. Ministerio de salud y Protección Social (2014). Informe nacional de la calidad del agua para consumo humano año 2013 con base en el IRCA. Bogotá.

5. Acra, A., Karahagopian, Y., Raffoul, Z., \& Dajani, R. (1980). Disinfection of oral rehydration solutions by sunlight. The Lancet, 316(8206), 1257-1258.

6. Acra, A., Jurdi, M., Mu'allem, H., Karahagopian, Y., \& Raffoul, Z. (1990). Water disinfection by solar radiation: assessment and application (No. 66e). International Development Research Centre.

7. Oates, P. M., Shanahan, P., \& Polz, M. F. (2003). Solar disinfection (SODIS): simulation of solar radiation for global assessment and application for point-of-use water treatment in Haiti. Water Research, 37(1), 4754.

8. Mbogo, S. A (2008). A novel technology to improve drinking water quality using natural 
treatment methods in rural

Tanzania. Journal of

Environmental Health; Mar 2008;

70, 7, 46-50.

9. Fisher, M. B., Iriarte, M., \&

Nelson, K. L. (2012). Solar water

disinfection (SODIS) of

Escherichia coli, Enterococcus

spp., and MS2 coliphage: effects

of additives and alternative

container materials. Water

research, 46(6), 1745-1754.

10. Kendricks, M. R., David, J. L.,

Sisco, T. E., \& Surbeck, C. Q. (2013). Solar Disinfection Water Treatment for a Community-Scale System: An Analysis of Design
Parameters for Humanitarian

Engineering

Projects. International Journal for

Service Learning in

Engineering, 8(1).

11. Dessie, A., Alemayehu, E., Mekonen, S., Legesse, W., Kloos, H., \& Ambelu, A. (2014). Solar disinfection: an approach for lowcost household water treatment technology in Southwestern

Ethiopia. Journal of

Environmental Health Science

and Engineering, 12(1), 25. 